\title{
UNUSUAL RECORD OF BONAPARTE'S GULL IN THE SIERRA SAN PEDRO MÁRTIR, BAJA CALIFORNIA
}

\author{
GORGONIO RUIZ-CAMPOS and GONZALO DE LEÓN-GIRÓN, Colección \\ Ornitológica, Facultad de Ciencias, Universidad Autónoma de Baja California, \\ Carretera Transpeninsular Ensenada-Tijuana No. 3917, Colonia Playitas, C.P. \\ 22860, Ensenada, Baja California, México; U.S. mailing address: PMB 064, P.O. Box \\ 189003, Coronado, California 92178; gruiz@uabc.edu.mx \\ HIRAM RAFAEL MORENO-HIGAREDA, Pro Esteros, A.C., Departamento de \\ Investigación, Calle Cuarta 210, Zona Centro, C. P. 22800, Ensenada, Baja California, \\ México
}

ARMANDO JESÚS CONTRERAS-BALDERAS, Cerro De La Conformidad 115, Las Puentes, Sector 2, C.P. 66460, San Nicolás de los Garza, Nuevo León, México

On 11 December 2015, during a snowstorm, De León-Girón found a Bonaparte's Gull (Chroicocephalus philadelphia) unable to fly and at the point of starvation near the ranger office of the Sierra de San Pedro Mártir National Park. The location is $30^{\circ}$ $59^{\prime} \mathrm{N}, 115^{\circ} 33^{\prime} 21^{\prime \prime} \mathrm{W}$, at an elevation of $2518 \mathrm{~m}$, and the vegetation is coniferous forest dominated by Pinus jeffreyi (Delgadillo-Rodríguez 2004). The bird died two days later. The specimen, an adult male, was prepared and deposited at the Universidad Autónoma de Baja California (UABC 2072; Figure 1). The pectoral mass of the dissected specimen confirmed the starved condition of this individual when it was found in the park during the snowstorm. Measurements include total length 360 $\mathrm{mm}$, wingspan $725 \mathrm{~mm}$, tarsus $35 \mathrm{~mm}$, wing length $237 \mathrm{~mm}$, tail $106 \mathrm{~mm}$, exposed culmen $29 \mathrm{~mm}$, and mass $115 \mathrm{~g}$, barely half the mean of $222 \mathrm{~g}$ reported for males by Burger and Gochfeld (2002).

In spite of numerous records of the species at and near sea level along both coasts of the Baja California peninsula, previous records from the interior of the peninsula are few, with none published before Wurster et al. (2001). None are from the Sierra San Pedro Mártir or as high as $2518 \mathrm{~m}$. Those in mountain habitats, from elevations $<1620 \mathrm{~m}$ at Laguna Hanson in the Sierra Juárez (one on 11 May 1997; four on 6 April 2000; Wurster et al. 2001) and Rancho Japá (14 May 2007, R. A. Erickson, via www.ebird.org), presumably represent spring migrants crossing from the Gulf of California to the Pacific coast. The date of our specimen suggests it was a fall migrant or winter visitor. Bonaparte's Gulls winter irregularly just north of the international border on the inland reservoirs of San Diego County (Unitt 2004), all at elevations below $920 \mathrm{~m}$ except for one report of one individual from Lake Cuyamaca (elevation $1412 \mathrm{~m}$ ), 10-18 December 2016 (photo by M. Colobianchi at https://ebird.org/ checklist/S32955657).

Ruiz-Campos and De León-Girón (2017) described a similar situation with the record of five Pacific Loons (Gavia pacifica) on this sky island at an elevation of 2428 $\mathrm{m}$, during a snowstorm on 15 November 2015. A month earlier than our Bonaparte's Gull, they presumably represented fall migrants crossing from the Pacific coast to the Gulf of California, retracing a path opposite the route by which the Pacific Loon departs the gulf in spring (Huey 1927). In this context, Grinnell (1928:55) had suggested the existence of a possible migratory route between the Pacific Ocean and the Gulf of California that crosses the mountain ranges of the northern Baja California peninsula. In both cases cited above, energetically spent individuals were downed by strong winds into unexpected habitats during the snowstorms.

We thank the park rangers of the San Pedro Mártir National Park for logistic support during our stay in the park, and M. E. Valles-Ríos for the preparation of the 


\section{NOTES}

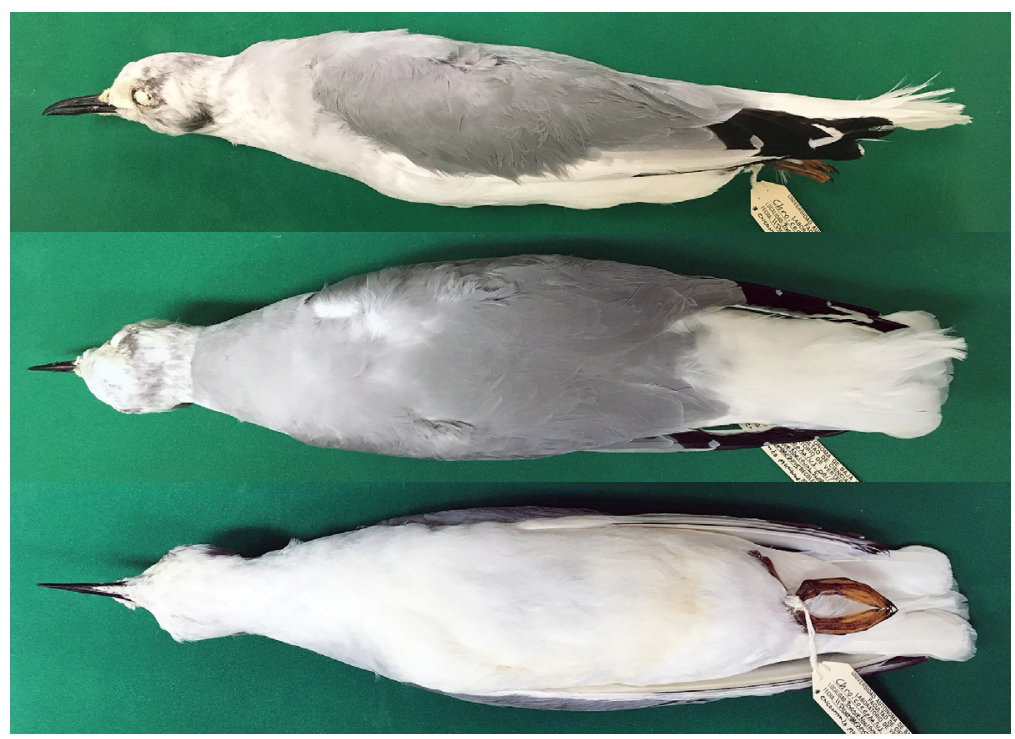

Figure 1. Male Bonaparte's Gull (UABC 2072) in lateral, dorsal and ventral view, collected 11 December 2015 at 2518 m in San Pedro Mártir National Park, Baja California.

\section{Photos by Gorgonio Ruiz-Campos}

specimen. Richard A. Erickson and Daniel D. Gibson made very useful comments that improved the clarity of the manuscript.

\section{LITERATURE CITED}

Burger, J., and Gochfeld, M. 2002. Bonaparte's Gull (Larus philadelphia), in The Birds of North America (A. Poole and F. Gill, eds.), no. 634. Birds N. Am., Inc., Philadelphia; doi.org/10.2173/bow.bongul.01.

Delgadillo-Rodríguez, J. 2004. El bosque de coníferas de la Sierra de San Pedro Mártir, Baja California, México. Secretaría de Medio Ambiente y Recursos Naturales-Instituto Nacional de Ecología, México, D.F.

Grinnell, J. 1928. A distributional summation of the ornithology of Lower California. Univ. Calif. Publ. Zool. 32:1-300.

Huey, L. M. 1927. Observations on the spring migration of Aphriza and Gavia in the Gulf of California. Auk 44:529-531; doi.org/10.2307/4074844.

Ruiz-Campos, G., and De León-Girón, G. D. 2017. Registro del colimbo pacífico ( $\mathrm{Ga}$ via pacifica) en el Parque Nacional Sierra de San Pedro Mártir, Baja California, México. Huitzil 18(1):11-15; doi.org/10.28947/hrmo.2017.18.1.257.

Unitt, P. 2004. San Diego County bird atlas. Proc. San Diego Soc. Nat. Hist. 39.

Wurster, T. E., Erickson, R. A., Hamilton, R. A., and Howell, S. N. G. 2001. Database of selected observations: An augment to new information on migrant birds in northern and central portions of the Baja California Peninsula, in Birds of the Baja California Peninsula: Status, Distribution, and Taxonomy (R. A. Erickson and S. N. G. Howell, eds.), pp. 204-237. Am. Birding Assoc. Monogr. Field Ornithol. 3. 